\title{
VARIATION OF SPECIFIC MORPHOLOGICAL TRAITS AND PLOIDY LEVEL OF FIVE AEGILOPS L. SPECIES IN MOROCCO.
}

\author{
Bouchra BELKADI, Nourredine ASSALI, Ouafae BENLHABIB
}

\begin{abstract}
Variation of specific morphological traits and ploidy level of five Aegilops L. species in Morocco.The genus Aegilops L. represents an important natural source of useful genes for wheat breeding, with particular emphasis on biotic and abiotic stress resistance. For successful crosses, the primarily step is to select appropriate Aegilops accessions. In this paper, we studied five Moroccan species of an Aegilops collection on the basis of spike structure and chromosome number. Twenty-eight specific morphological characters were used to differentiate the species. Statistical analyses, in particular the DFA, allowed the characterization of the genetic variability of the species; the two first standardized axes explained $96,2 \%$ of the total variability and $100 \%$ of the entities were classified within their own group. In addition, the dendrogram constructed using morphological data reveals a significant variability within and between species. Cytogenetic study revealed four species, A. geniculata Roth, A. triuncialis L., A. ventricosa Tausch and A. peregrina Maire \& Weiller, to be tetraploid. However, A. neglecta Req. ex. Bertol., where only two accessions are represented in the collection, revealed to be hexaploid, and can then be classified as A. neglecta subsp. recta Chennav.
\end{abstract}

Key words. Aegilops, Variation, Morphology, Ploidy, Morocco.

RÉSUMÉ. Variation des caractères morphologiques spécifiques et niveau de plö̈die de cinq espèces Aegilops L. au Maroc. Le genre Aegilops L. représente une importante source de gènes, potentiellement utilisables dans l'amélioration des blés cultivés (Triticum spp.) notamment pour la résistance aux stress biotiques et abiotiques. Le choix des accessions Aegilops à employer, dans un programme d'hybridation interspécifique, nécessite une caractérisation taxonomique et une évaluation préalables. L'objectif de ce travail a été d'étudier des accessions, appartenant à 5 espèces marocaines constituant une collection d'Aegilops, sur la base de caractères morphologiques spécifiques de l'épi et du niveau de ploïdie. La caractérisation phénotypique a été basée sur l'étude de 28 caractères morphologiques qui discriminent entre les espèces. Les résultats des analyses statistiques, en particulier de l'AFD, ont permis de caractériser la variabilité génétique de ces espèces et ont donné un pourcentage d'appartenance à l'espèce de $100 \%$. Aussi, les deux premiers axes standardisés expliquent $96,2 \%$ de la variabilité totale. Un dendrogramme a été aussi construit, révélant une variabilité interspécifique. L'étude cytogénétique a révélé une tétraploïdie pour A. geniculata Roth, A. triuncialis L., A. ventricosa Tausch et A. peregrina Maire \& Weiller. Quant à A. neglecta Req. ex. Bertol., une hexaploïdie a été mise en évidence pour les deux uniques accessions disponibles dans la collection, permettant de leur attribuer le nom A. neglecta subsp. recta Chennav.

Mots clés. Aegilops, Variation, Morphologie, Ploïdie, Maroc.

\section{INTRODUCTION}

The genus Aegilops L. has been one of the most intensively studied group among grasses, especially since it was confirmed to have a close relationship with cultivated wheat. Aegilops L. belongs to the family of Poaceae (Gramineae), first group described by Jussieu 
in his book "Genera Plantarum" (Jussieu, 1789). Since then, several authors have concentrated their studies on this genus (Boissier, 1884; Zhukovsky, 1928; Eig, 1929; Sears, 1941; Kihara, 1946; Bor et al., 1968; Hammer, 1980; Baum et al., 1987; Perino \& Prceddu, 1990 and Van Slageren, 1994).

Aegilops species are widely represented in Mediterranean and West Asian regions (Sakamoto \& Kobayashi, 1980). They are well adapted to diverse disturbed environments, pastures, edges and within cultivated fields; which translate a huge morphological variability of the spike.

According to the classification of Van Slageren, the Aegilops genus comprises 22 diploid, tetraploid and hexaploid species (Van Slageren, 1994). The genus would probably originate from Transcaucasia (Hammer, 1980). All species are annual and autogame. The diversity of Aegilops make its taxonomy especially difficult. Therefore, for a proper evaluation of the species, it is necessary to check the ploidy level and the chromosome morphology. Indeed, an unacquainted observer may fail to distinguish between certain Aegilops species with different ploidy levels (tetra- vs hexaploid) if the observations are based only on morphological characteristics.

Cytogenetic studies of this genus have been especially used to establish genetic relationships in biosystematics research, and for assisted crop improvement programs. It is known that Aegilops species forms series of allopolyploids ranging from diploids $(2 n=4 x=$ 14) to hexaploids $(2 n=6 x=42)$, with a basic set of chromosomes $x=7$ (Sakamura, 1918). Senjaninova - Korczagina was probably the first author who worked on chromosome morphology in Aegilops (Senjaninova Korczagina, 1932). Chennaveeraiah described the chromosomes morphology of 21 Aegilops diploids and polyploids (Chennaveeraiah, 1960). Despite this large amount of works (Zurabishvili et al., 1978; Wains \& Barnhart,
1991), there is still a need to extend cytogenetic investigation to further geographical areas. However, the majority of these studies were criticized for their limitation to few accessions of each species.

In Morocco, it has been reported, in an old herbarium database, seven tetraploid species of Aegilops (Kimber \& Feldman, 1987; Van Slageren, 1994). Only five species were collected in 1994 - 1995 and identified on the basis of the morphological features of their inflorescences (Benlhabib et al., 2001). According to Kihara (1946) and Kimber (1983), their genome formula has been determined as: A. geniculata Roth (MU), A. triuncialis L. (UC), A. ventricosa Tausch (DN), A. neglecta Req. ex. Bertol. (UM or UMN) and A. peregrina Maire \& Weiller (SU). They were distributed mainly in the northern area of the Rif mountains, the Central Plateaus of Saïs and Zaeir, the High and Middle Atlas mountains and the western coastal area from south of Tanger to north of Agadir. The first two species are widely distributed throughout the country. A. ventricosa grows on intermediate to high altitudes sites in humid and cold areas. A. neglecta seems to prefer littoral zones and never grows on dense surfaces but rather as loosely dispersed population (Benlhabib et al., 2001). A. peregrina was recently collected in Rabat areas; it has been mentioned in Morocco previously in the "Flore de l'Afrique du Nord" (Maire, 1955), in the "Nouvelle flore d'Algérie et des régions désertiques méridionales" (Querzel \& Santa, 1962-1963) and in the "Catalogue des plantes vasculaires du Nord du Maroc incluant des clés d'identification" (Valdés et al., 2002).

In order to understand the taxonomic position of those Aegilops species growing in Morocco, a biosystematic study with several approaches was conducted. The present work deals with specific morphological traits and ploidy level. This characterization would allow us to confirm the diagnose of the prospectors 
and to study the phenotypical variability within three of the five species of the collection.

\section{MATERIALS AND METHODS}

\section{Plant Material}

The morphological characterization was performed on dried plants belonging to the genus Aegilops that have been collected during summer seasons of 1994 and 1995 from different regions of Morocco. These plants were collected from natural populations growing on roadsides, pastures and edges of cultivated fields. Benlhabib et al. (2001) have described in detail these collection sites and populations. On the other hand, cytogenetic study was carried on root tips of some seedling samples of the collection.

The entire collection enclosing 151 accessions is maintained, by the Cereal Cytogenetic and Biotechnology Laboratory at the Agronomy Plants Breeding Department; I.A.V. Hassan II, as herbarium and stored seeds at $-20^{\circ} \mathrm{C}$. It is composed by $115 \mathrm{~A}$. geniculata, 25 A. triuncialis, 7 A. ventricosa, 2 A. neglecta and $2 A$. peregrina accessions.

\section{Morphological data}

One hundred thirty nine accessions among the 151 collected were characterized using 28 specific morphological traits. The traits studied included characteristics of the spike, spiklets, glume, lemma, palea and awns (tab. 1). Three to six representative spikes were used in this investigation.

\section{Statistical analysis}

The variance analysis was used to test the significance of the variation among accessions for the 28 traits studied. The correlation coefficients between traits were estimated by the mean value of accessions over locations. Analysis of variance, means and coefficient of variation for traits were calculated with the
SAS program (SAS institut, 1989).

A discriminate factorial analysis (DFA) was also carried out on the correlation matrix of the traits using the STATITCF program.

\begin{tabular}{lc}
\hline \multicolumn{1}{c}{ Characters } & Abbreviation \\
\hline Spike length & SL \\
Spike wide & SW \\
Spiklets number & SN \\
Number of steril spiklets & NSS \\
Number of rudimentary spiklets & NRS \\
Awns number on lower glumes & ANLG \\
Awns number on upper glumes & ANUG \\
Teeth number on lower glumes & TNLG \\
Teeth number on upper glumes & TNUG \\
Length of lower glumes & LLG \\
Length of upper glumes & LUG \\
Wide of lower glumes & WLG \\
Shortest awns of the lower glumes & SALG \\
Longest awns of the lower glumes & LALG \\
Shortest awns of the upper glumes & SAUG \\
Longest awns of the upper glumes & LAUG \\
Length of lower lemmas & LLL \\
Length of upper lemmas & LUL \\
Awns number on lower lemmas & ANLL \\
Awns number on upper lemmas & ANUL \\
Teeth number on lower lemmas & TNLL \\
Teeth number on upper lemmas & TNUL \\
Shortest awns of the lower lemmas & SALL \\
Longest awns of the lower lemmas & LALL \\
Shortest awns of the upper lemmas & SAUL \\
Longest awns of the upper lemmas & LAUL \\
Length of lower palea & LLP \\
Length of upper palea & LUP \\
\hline
\end{tabular}

Table 1. Morphological traits studied on the Aegilops collection. Measures in $\mathrm{mm}$. Caractères morphologiques étudiées sur la collection d'Aegilops. Measures à $\mathrm{mm}$. 
Euclidean distance was calculated upon the three first standardized principal components, this distance called "Mahalanobis generalized distance" was used (Llauradó \& MorenoGonzalez, 1993).

Cluster analysis using the unweighted pair group method (UPGMA) based on arithmetic averages were carried out using the Cluster procedure of SAS Software 1987 (SAS institut, 1989). The euclidean distances among populations calculated on the first three standardized axes were computed in this procedure. Dendrograms showing the phenotypic relationships were obtained by the TREE procedure of SAS (SAS institut, 1989).

\section{Cytological data}

The five Aegilops species collected in Morocco were used for chromosomal analysis. Two to four accessions per species were analyzed with the cytological method described by Sharma (1982). Sterilized seeds were germinated in Petri dishes at room temperature. Young root tips were pre-treated with 2 or $4 \%$ alpha-bromonaphtalene solution for 24 hours, then fixed in a mixture of ethanol and glacial acetic acid (3:1, v/v) before their storage at $4^{\circ} \mathrm{C}$. Fixed root tips were hydrolyzed in $1 \mathrm{~N}$ hydrochloric acid at $60^{\circ} \mathrm{C}$ for $10 \mathrm{~min}$, stained in $1 \%$ carmine solution for 1 to 2 hours, then squashed in $4 \%$ acetic acid. Cells with wellspread chromosome complements were scored and photographed for chromosomal morphology determination. Photographs were taken with an Olympus micromaster camera at 400x magnification.

\section{RESULTS AND DISCUSSION}

\section{Ploidy level}

The observation of somatic metaphase plates of each species shows a constant chromosome number between scored cells. Table 2 summarized the ploidy levels of
Moroccan Aegilops studied and the genomic constitution (column 5) as established by Kihara (1946) and Kimber (1983) on the base of meiotic chromosome pairing in hybrids.

We have been able to confirm the tetraploid level $(2 n=4 x=28)$ of the four species: A. geniculata (fig. 1), A. triuncialis, $A$. ventricosa and $A$. peregrina ( $A$. variabilis Eig.) as have been mentioned by several authors (Chennaveeraiah, 1960; Gupta \& Baum, 1986 and Kimber \& Feldman, 1987). Both accessions of $A$. neglecta presented however a hexaploid number of chromosomes $(2 n=6 x=42)$. It can be then classified as " $A$. neglecta subsp. recta Chennav" or "A. recta" according to Kimber and Feldman (1987) (fig. 2). The hexaploid form of $A$. neglecta species has not been mentioned by Kimber and Feldman (1987) neither in Morocco nor in North Africa. Kimber \& Feldman (1987) have reported that this hexaploid cytotype or race is relatively common in Greece and western Turkey and is found in Portugal, Spain, France, Yugoslavia and Italy. Van Slageren (1994) was however astonished that the hexaploid form $A$. neglecta is present in those countries without mentioning Algeria from where the lectotype specimen of $A$. neglecta subsp. recta is originates. In Morocco, Kimber \& Feldman (1987) reported the tetraploid form of A. neglecta, which doesn't exist within the studied collection. This cytotype has certainly not been crossed during the Aegilops prospecting trip.

The two forms of the A. neglecta constitute a taxonomic difficulty since they cannot be distinguished on the basis of their phenotype. In fact, when based only on the morphological traits of the spike, spiklets, sterile glumes, lemmas and paleas, both 52 and 66 accessions are classified as $A$. neglecta with no regards to the cytotype group. Kimber \& Feldman (1987) described the hexaploid form with a fertile terminal spiklet whereas the tetraploid form with sterile spiklet; they specified that the plants were growing under controlled 


\begin{tabular}{|c|c|c|c|c|c|}
\hline Species & $\begin{array}{l}\text { Number of } \\
\text { Accession }\end{array}$ & $\begin{array}{l}\text { Accession } \\
\text { reference }\end{array}$ & Origin & Genome & ploidy level \\
\hline \multirow[t]{4}{*}{ A. geniculata } & 4 & 24 & Oujda $3 \mathrm{~km}$ from Beni Drar & MU & $2 n=4 x=28$ \\
\hline & & 51 & $\begin{array}{l}\text { Larach-Ksar al kebir } 8 \mathrm{~km} \\
\text { to Ksar al kebir }\end{array}$ & & \\
\hline & & 70 & $\begin{array}{l}15 \mathrm{~km} \text { from Aguel mous to } \\
\text { Kénifra }\left(467^{\circ}, 273^{\circ} \text {, }\right. \\
1000 \mathrm{~m})\end{array}$ & & \\
\hline & & 80 & $\begin{array}{l}13 \mathrm{~km} \text { from Aïn louh to } \\
\text { Azrou }\end{array}$ & & \\
\hline \multirow[t]{4}{*}{ A. triuncialis } & 4 & 1 & $\begin{array}{l}14 \mathrm{~km} \text { from Rabat to } \\
\text { Meknès }\end{array}$ & UC & $2 n=4 x=28$ \\
\hline & & 7 & $\begin{array}{l}2 \mathrm{~km} \text { from El Hajeb to } \\
\text { Azrou }\end{array}$ & & \\
\hline & & 30 & $\begin{array}{l}1 \mathrm{~km} \text { from Ben abdellah to } \\
\text { Targoust }\end{array}$ & & \\
\hline & & 120 & $\begin{array}{l}20 \mathrm{~km} \text { from Aït Atab to } \\
\text { Ouzoud }\end{array}$ & & \\
\hline \multirow[t]{4}{*}{ A. ventricosa } & 4 & 12 & $1 \mathrm{~km}$ to Azrou & DN & $2 n=4 x=28$ \\
\hline & & 15 & $10 \mathrm{~km}$ of Ifrane to Azrou & & \\
\hline & & 20 & $\begin{array}{l}\text { Sefrou, Station } \\
\text { expérimentale Annacer }\end{array}$ & & \\
\hline & & 68 & $\begin{array}{l}6 \mathrm{~km} \text { from Oulmes to } \\
\text { Aguelmous } \\
(444,310,1000)\end{array}$ & & \\
\hline \multirow[t]{2}{*}{$\begin{array}{l}\text { A. neglecta ssp. } \\
\text { recta }\end{array}$} & 2 & 52 & $\begin{array}{l}17 \mathrm{~km} \text { from Ksar El Kebir } \\
\text { to Souk Al Arbaa }\end{array}$ & UMN & $2 n=6 x=42$ \\
\hline & & 66 & $\begin{array}{l}6 \mathrm{~km} \text { from Oulmès to } \\
\text { Aguelmous }\end{array}$ & & \\
\hline \multirow[t]{2}{*}{ A. peregrina } & 2 & 151 & Rabat road to Casablanca & SU & $2 n=4 x=28$ \\
\hline & & 152 & $\begin{array}{l}\text { Rabat to Casablanca, } \\
\text { ceinture verte }\end{array}$ & & \\
\hline
\end{tabular}

Table 2. Ploidy level of species and their origin. Niveau de plö̈die des espèces et leurs origines.

conditions. Van Slageren (1994) thinks that the fertility of upper spiklet cannot be a discriminat character between the two species. His justification is that under favorable conditions, the upper spiklet of the tetraploid species can carry seeds. On the other side, terminal spiklet of hexaploid form can be sterile as is the case of our two Moroccan accessions of A. neglecta. Therefore, the examination of the ploidy is indispensable to confirm the cytotype group. Then, more investigation between both tetraploïd and hexaploïd forms of A. neglecta is needed as prospecting sites in the North part of Morocco where the tetraploid 


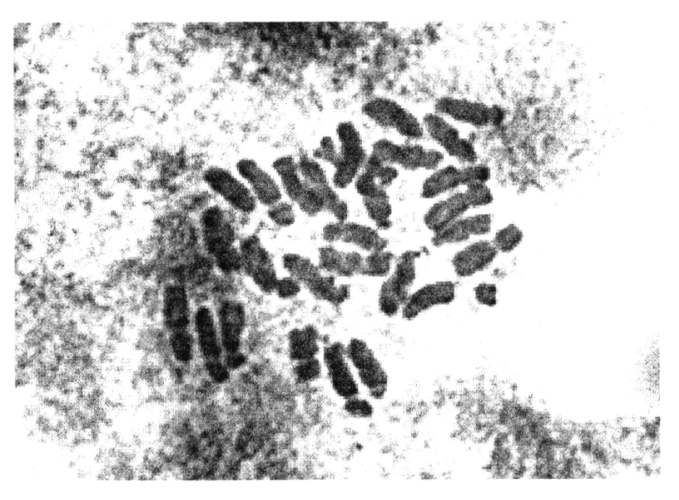

Figure 1. A. geniculata Roth.

A. neglecta has been reported (Valdés et al., 2002).

The cytological analysis of natural populations remains an effective tool to check the taxonomic classification of a specie (Davis \& Heywood, 1973). Nevertheless, the chromosome number, is generally not enough to establish the relationship between species. According to Chennaveeraiah (1960), morphological characterization of the chromosomes shows differences that influence plant shape, which make it tool useful in some systematical works. The wide variations in the chromosome morphology explain the huge morphological variation found among accession originated from different geographical areas of a same polyploid specie (Zohary \& Feldman, 1962).

In addition, diversity in chromosome shape (length, width) has been observed while studying the genomes (result not shown). Two explanations to this variation are plausible, either chromosome have different sizes and/or forms, or the method of preparing slides causes heterogeneity in chromosome compaction. Therefore, using other cytological methods, such as the binding techniques or the in situ hybridization, could help in producing accurate data.

\section{Morphological characterization}

a) Morphological variation:

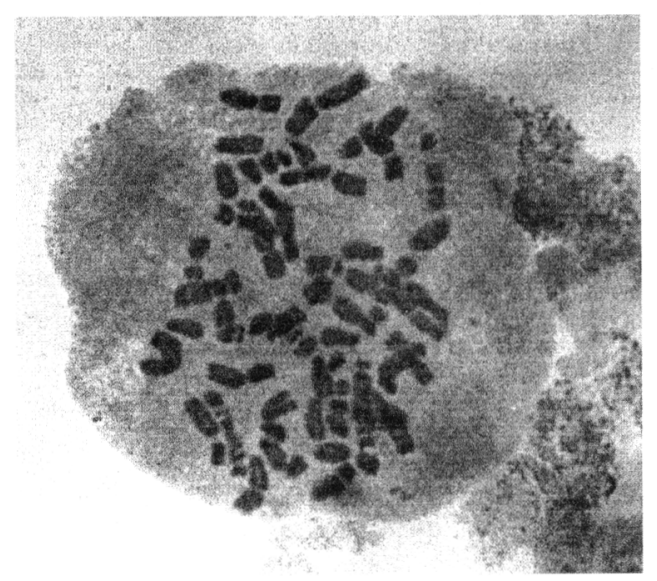

Figure 2. A. neglecta subsp. recta Chennav.

The variance analysis performed on 28 quantitative morphological descriptors showed that the differences between species are statistically significant (tab. 3). Most coefficients of variation were ranged between $0-30 \%$. The number of teeth on upper and lower glumes (TNUG, TNLG) and the number of teeth on upper lemma (TNUL) reached 90 , 129 , and $257 \%$ of variation, respectively. Few traits presented less than $10 \%$ of variation, such as the number of rudimentary spiklets (NRS). They do not discriminate between species but stand for specific descriptor of the genus. Slight variations can be of particular value for some species diagnostic; for instance the presence of teeth on lower and upper glumes (TNLG, TNUG), one awn on lower and upper lemmas (ANLL, ANUL) and one awn on upper glume (ANUG), which are all specific to $A$. ventricosa.

A. neglecta and A. peregrina data couldn't be analyzed by the statistical methods, because they were only two accessions within the collection.

A. geniculata species presented the largest number of significant traits. This variation is related to the diversity of its habitats (Allard, 1988). In fact, A. geniculata was collected from different environments in Morocco, from 


\begin{tabular}{|c|c|c|c|c|c|c|c|c|c|c|c|c|}
\hline \multirow{3}{*}{$\begin{array}{l}\text { Characters } \\
\text { SL }\end{array}$} & \multicolumn{3}{|c|}{ Aegylops } & \multicolumn{3}{|c|}{ A. geniculata } & \multicolumn{3}{|c|}{ A. triuncialis } & \multicolumn{3}{|c|}{ A. ventricosa } \\
\hline & Mean & cv in & ter & Mean & $\mathrm{CV}$ ir & atra & Mean & $\mathrm{CV}$ in & ntra & Mean & $\mathrm{CV}$ int & tra \\
\hline & 34,35 & 28,8 & $* * *$ & 24,9 & 14,6 & $* * *$ & 59,2 & 10,3 & $* * *$ & 85,1 & 16,23 & $* * *$ \\
\hline SW & 5,10 & 25 & $* * *$ & 5,32 & 25,5 & $* * *$ & 4,36 & 19 & NS & 3,65 & 21,5 & NS \\
\hline SN & 4,32 & 15 & $* * *$ & 3,67 & 15 & NS & 5,06 & 10,5 & NS & 9,60 & 9,5 & $* * *$ \\
\hline NSS & 1,00 & 56 & $* * *$ & 1,03 & 54 & NS & 0,80 & 75 & $* * *$ & 1,00 & 0 & - \\
\hline NRS & 1,35 & 2 & $* * *$ & 1,03 & 18 & NS & 2,77 & 16,5 & NS & 0,34 & 132 & NS \\
\hline ANLG & 3,56 & 28 & $* * *$ & 4,09 & 22 & $* * *$ & 2,82 & 13,5 & NS & 0,13 & 264 & NS \\
\hline ANUG & 4,14 & 22 & $* * *$ & 4,78 & 22 & $* * *$ & 3,00 & 0 & NS & 1,00 & 0 & - \\
\hline TNLG & 0,16 & 129 & $* * *$ & 0,03 & 548 & NS & 0,08 & 310 & $* *$ & 1,86 & 18,5 & NS \\
\hline TNUG & 0,11 & 90 & $* * *$ & 0 & - & NS & 0,00 & - & NS & 1,78 & 23,5 & NS \\
\hline LLG & 4,00 & 23 & $* * *$ & 4,13 & 23 & $* *$ & 3,50 & 20 & NS & 3,73 & 23 & NS \\
\hline LUG & 4,55 & 24,5 & $* * *$ & 3,96 & 28 & $* *$ & 6,87 & 13,5 & NS & 5,69 & 24 & NS \\
\hline WLG & 2,00 & 31,5 & $* * *$ & 1,97 & 34,5 & $* *$ & 2,45 & 16,5 & NS & 2,19 & 33 & $*$ \\
\hline SALG & 14,95 & 40 & $* * *$ & 14,26 & 36 & NS & 22,91 & 40,5 & NS & 0,00 & - & - \\
\hline LALG & 21,80 & 25,5 & $* * *$ & 21,42 & 24,5 & $* *$ & 30,15 & 24 & NS & 0,00 & - & - \\
\hline SAUG & 21,39 & 33 & $* * *$ & 15,3 & 34,5 & NS & 50,98 & 25 & NS & 9,69 & 48 & NS \\
\hline LAUG & 29,97 & 22 & $* * *$ & 24,27 & 21 & $* *$ & 62,00 & 17,5 & NS & 9,69 & 48 & NS \\
\hline LLL & 8,25 & 9 & $* * *$ & 7,93 & 10 & NS & 9,65 & 6,5 & NS & 7,39 & 14 & NS \\
\hline LUL & 4,79 & 27 & $* * *$ & 3,86 & 31 & NS & 8,09 & 11 & NS & 6,04 & 36 & NS \\
\hline ANLL & 2,14 & 29,5 & $* * *$ & 2,30 & 30 & $* * *$ & 2,06 & 12 & $*$ & 1,00 & 0 & - \\
\hline ANUL & 2,74 & 27 & $* * *$ & 2,86 & 28 & $* * *$ & 3,00 & 0 & NS & 1,00 & 0 & - \\
\hline TNLL & 0,79 & 66 & $* * *$ & 0,67 & 75 & $* * *$ & 0,98 & 38 & $*$ & 1,13 & 30,5 & NS \\
\hline TNUL & 0,14 & 257 & $* * *$ & 0,08 & 429 & $*$ & 0,00 & - & NS & 1,08 & 54 & NS \\
\hline SALL & 7,86 & 60,5 & $* * *$ & 9,33 & 54 & $* * *$ & 2,27 & 74,5 & NS & 9,21 & 36 & NS \\
\hline LALL & 13,86 & 30 & $* * *$ & 16,58 & 27 & $* *$ & 5,43 & 34,5 & $*$ & 9,21 & 36 & NS \\
\hline SAUL & 10,90 & 65 & $* * *$ & 10,87 & 51 & $* * *$ & 7,77 & 117 & NS & 25,34 & 32 & $* * *$ \\
\hline LAUL & 22,15 & 34 & $* * *$ & 18,83 & 28,5 & $* *$ & 38,65 & 31 & NS & 25,34 & 32 & $* * *$ \\
\hline LLP & 8,39 & 10 & $* * *$ & 8,11 & 10 & $* *$ & 9,88 & 7 & NS & 6,69 & 19 & NS \\
\hline LUP & 4,97 & 30 & $* * *$ & 3,94 & 38,5 & $* *$ & 8,51 & 10 & NS & 6,08 & 22 & $*$ \\
\hline
\end{tabular}

NS: no significant; *: significant at $5 \%$;*: significant at $1 \%$; **: significant at $1 \%$.

Table 3. Means and coefficients of variation of morphological traits studied. Moyennes et coefficients de variation des caractères morphologiques étudiés.

over $1700 \mathrm{~m}$ of altitude, down to coastal zones such as Rabat and Kenitra area.

The studied descriptors were related; many were significantly correlated (tab. 4). The highest correlations was those between spike length SL and the number of spikelets SN ( $r=$ 0.866 ), and between the longest LAUG and shortest awn of the upper glume SAUG $(r=0.93)$. The correlation between both traits is expected since they are biologically dependent. In fact, these correlations indicated probably that two linked genetic factors are controlling both traits. Less predictable correlation are those between the number of rudimentary spiklets NRS and the shortest and longest awns of upper glumes (SAUG and LAUG). Negative correlations were those between awns number on lower ANLG or upper ANUG glumes from one side and the number of spiklets $\mathrm{SN}$ or the spike length SL from the other side.

b) Discriminate factorial analysis:

Genetic distances between groups are based on similarities and give good picture of the relationship between accessions. Mahalanobis distance estimated through calculation showed that the closest two species are $A$. geniculata and $A$. triuncialis $(\mathrm{d}=2,61)$ while the farthest species are $A$. recta and $A$. peregrina $(\mathrm{d}=7,79)$. This statement confirms Benlhabib et al.'s results when using 


\begin{tabular}{llllllll}
\hline & SL & SN & ANLG & ANUG & SAUG & LAUG & LAUL \\
\hline SL & 1.000 & & & & & & \\
SN & 0.866 & 1.000 & & & & & \\
ANLG & -0.674 & -0.709 & 1.000 & & & & \\
ANUG & -0.681 & -0.649 & 0.802 & 1.000 & & & \\
SAUG & 0.523 & 0.154 & -0.196 & -0.335 & 1.000 & & \\
LAUG & 0.453 & 0.069 & -0.052 & -0.192 & 0.930 & 1.000 & \\
LAUL & 0.593 & 0.320 & -0.174 & -0.208 & 0.745 & 0.802 & 1.000 \\
\hline
\end{tabular}

Table 4: Correlation coefficients between some traits in Aegilops. Coefficients de corrélation entre quelques caractères chez les Aegilops.

agromorphological traits of the same collection (2001).

Plotting accessions in new groups showed that they were assembled within their own species. The discriminate analysis confirm that all the 28 traits used in this study are characteristic to the species and are therefore useful for classification. In Benlhabib et al.'s investigations, where agro-morphological criteria were used, only $86,6 \%$ of the variation could be explained by the same analysis method. For instance, $13.4 \%$ of A. geniculata accessions was misclassified. This dispersion is explained by the morphological and phenological diversity within this species as stated by Zaharieva while describing Bulgarian collection (Zaharieva, 1999).

The discriminate factorial analysis (DFA) evaluates the discriminating degree of the used traits. The analysis computes new homogeneous groups with optimal similarities. A such method was largely used by several authors when studying Aegilops and Triticum genus (Baum, 1977).

Hackel, (1887), Pilger (1945) and Maire (1955) classified the Triticeae genera on morphological traits. Stebbins and Crampton (1959) have evaluated the usefulness of many characters specific to Triticeae of North America. Later on, various numerical techniques were used on different morphological characters of Triticeae by Baum (1978a, 1978b) and Baum et al. (1987) in order to define an "Operational Taxonomic Units"
(OTUs). They evaluated the significance of 45 traits and their relationships for the classification and diagnosis purposes.

The first three principal axes accounted for $98,7 \%$ of the total variation. Axis 1 alone accounts for $68,6 \%$ variation. The relative magnitude of eigenvectors from the first axes (tab. 5) indicates that the lengths of upper glume (LUG), lemma (LUL) and palea (LUP), the shortest awns of upper glume (SAUG), the wide of lower glume (WLG) and the longest awns of upper lemma (LAUL) and shortest awns of lower lemma (SALL) were determinant for the affectation of the accession within the clusters. The second axis, which accounted $13,48 \%$ of variation, is significantly linked to three criteria, the awns number of the upper lemma (ANUL), the longest awns of the lower glumes (LALG) and the shortest awns of the upper lemma (SAUL). This analysis underlines that the shape of upper and lower glumes and the awn length of upper lemma are the traits, which have the largest contribution in the phenotypic variation observed among Aegilops accessions and between the species.

Plotting the accessions along the two first axes differentiates clearly between the five species (fig. 3). In spite of the high number of accessions studied, A. geniculata was projected on the positive side of the first axis forming a consistent group. All the others species, was projected on the negative side of the same axis. This shows the discriminating capacity of the morphological traits used. A. geniculata is 
DISCRIMINANT AXES

\begin{tabular}{ccccc}
\hline Traits & \multicolumn{2}{c}{ Axis 1 } & \multicolumn{2}{c}{ Axis 2 } \\
\hline SL & -0.8750 & 0.7656 & 0.4842 & 0.2344 \\
SN & -0.5898 & 0.3478 & 0.8004 & 0.6407 \\
NRS & -0.8389 & 0.7037 & -0.5270 & 0.2777 \\
ANLG & 0.6894 & 0.4753 & -0.7168 & 0.5138 \\
ANUG & 0.8227 & 0.6768 & -0.5477 & 0.2999 \\
LLG & -0.8829 & 0.7795 & -0.2648 & 0.0701 \\
LUG & $\mathbf{- 0 . 9 6 4 2}$ & $\mathbf{0 . 9 2 9 7}$ & 0.0262 & 0.0007 \\
WLG & $\mathbf{0 . 8 6 0}$ & $\mathbf{0 . 7 4 0 7}$ & -0.0172 & 0.0003 \\
SALG & -0.4950 & 0.2451 & -0.8278 & 0.6853 \\
LALG & -0.3229 & 0.1042 & $-\mathbf{0 . 9 2 0 0}$ & $\mathbf{0 . 8 4 6 4}$ \\
SAUG & $\mathbf{- 0 . 9 0 1 1}$ & $\mathbf{0 . 8 1 1 9}$ & -0.4152 & 0.1724 \\
LAUG & -0.8386 & 0.7033 & -0.5225 & 0.2730 \\
LLL & -0.8271 & 0.6842 & -0.5165 & 0.2667 \\
LUL & $\mathbf{- . 9 9 6 8}$ & $\mathbf{0 . 9 9 3 7}$ & -0.0395 & 0.0016 \\
ANUL & 0.1114 & 0.0124 & $\mathbf{- 0 . 9 7 9 8}$ & $\mathbf{0 . 9 6 0 0}$ \\
SALL & $\mathbf{0 . 9 5 0 1}$ & $\mathbf{0 . 9 0 2 7}$ & 0.2772 & 0.0768 \\
LALL & $\mathbf{0 . 9 3 8 9}$ & $\mathbf{0 . 8 8 1 5}$ & -0.066 & 0.0044 \\
SAUL & 0.1549 & 0.0240 & $\mathbf{0 . 9 4 7 8}$ & $\mathbf{0 . 8 9 8 4}$ \\
LAUL & $\mathbf{0 . 9 0 8 3}$ & $\mathbf{0 . 8 2 5 1}$ & -0.1546 & 0.0239 \\
LLP & -0.6886 & 0.4742 & -0.7113 & 0.5060 \\
LUP & $\mathbf{0 . 9 9 4 9}$ & $\mathbf{0 . 9 8 9 7}$ & -0.0822 & 0.0068 \\
\hline
\end{tabular}

For every axis: Column one: correlations between classes. Column two: correlations square

Table 5. Eigenvectors of axes 1 and 2 in the FDA. Contribution des variables à l'explication des axes 1 et 2 de l'AFD.

characterized by an ovoid shape of the spike with 3-4 spiklets. The lower spiklets is subventricose. Most of the characters studied were variable except the length of lower glumes, lemmas and paleas. This variation is in agreement with other investigations (Zaharieva et al, 1999) which reported a large variation in relation to the growing environment and to the specific adaptation of this species. The distinctive characters of $A$. geniculata from the four others species were ANUG and ANLL. The number of awns on the upper glume of $A$. geniculata is generally 3 but can vary from 2 to 6 and the number of awns on the lower lemma is 2 plus one tooth.

A. ventricosa was projected on the extreme positive side of axis 2 which separate it from $A$. triuncialis, A. peregrina and A. reta. A. ventricosa is characterized by its highest spiklets number (SN) and the only one awn on the upper glume and lemma (ANUG, ANUL). It also has a long spike, an oval spiklets, a strongly overlapping glumes and thick tips with two teeth separated with a broad sinus.

A. triuncialis was projected at the negative sides of the two axes not far from $A$. peregrina and $A$. recta confirming the close relationship between those three species. A. triuncialis is characterized by a subcylindrical spike. Its glumes are coriaceous with 2-3 awns. The central awn of the glumes of lower spiklets is shorter than the laterals. The central awn of the glumes of the terminal spiklets is contrarily longer and wider than the laterals and is often the longest awn on the spike.

$A$. peregrina and $A$. recta both were represented by only 2 accessions which were projected on the negative side of axis 1. A. 


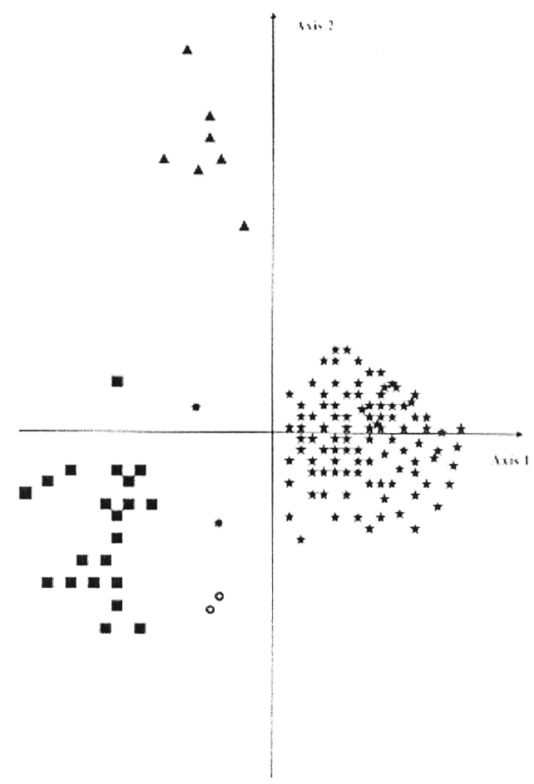

Fig 3. Plot of the discriminant scores of the 28 characters of on the first two axes. Legend: $\star A$. geniculata; $\boldsymbol{x}$ A truncalis; $\Delta$ A. ventricosa; O A. triaristata; A. peregrina.Projection des accessions Aegilops sur les deux premiers axes sur la base des 28 caractères.

recta has a lanceolate spike, narrowly ovoid in the upper part. Its glumes are coriaceous, broad and shorter than the lemma which separate the hexaploid from the tetraploid forms according to Kimber \& Feldman (1987). A. peregrina has a broad spike with 2 to 3 rudimentary spiklets. Its glumes are tough and rough with equally long, wide and parallel nerves.

\section{c) Cluster analysis:}

In order to establish the relationship between Aegilops species collected in Morocco, a dendrogram was constructed based on the similarity matrix (fig. 4). This tree shows a good separation between five clusters each corresponding to a define species. This dendrogram is in perfect agreement with the DFA analysis, but also provides additional information concerning the relationship between the accessions. A. geniculata and $A$. peregrina were close to each others with $50 \%$ similarity; both of them were close to $A$. recta which was in turn more close to A. triuncialis. The four former species are forming a cluster with $25 \%$ similarity and are sharing together the $U$ genome, which has probably a specific effect. Such similarity has been mentioned in a study based on RAPD markers (Monte et al., 1999). The last sub cluster corresponds the $A$. ventricosa group, which is clearly dissimilar from the other species which are not carrying $\mathrm{D}$ genome. It is established that $\mathrm{D}$ genome has undergone during its evolution few changes in comparison to other genomes, and seems therefore to be more homogeneous and have better distinctiveness within the Triticeae genus (Badaeva et al., 1996 and Damania, 1993).

\section{CONCLUSION}

The cytological investigation indicates that the studied collection of Moroccan Aegilops contains four tetraploid ( $A$. geniculata, A. triuncialis, A. ventricosa and $A$. peregrina) and one hexaploid (A. neglecta subsp. Recta) species. The study of the morphological traits carried on a set of 28 discriminating characters, confirmed a large phenotypic variation both between and within species. Through numerical analysis, specific traits were clearly justified to be useful for the species identification.

The approch used in this study was however insufficient to establish the genetic structure of the Moroccan Aegilops. Therefore, DNA analyses combined with morphological and cytogenetic techniques is needed for such objective. The genetic resources, their classification, conservation and utilization are essential for sustainable agriculture and crop improvement. For effective plant germoplasm exploration, one must link between classical and new molecular techniques. In coming paper, we will be reporting more details about 


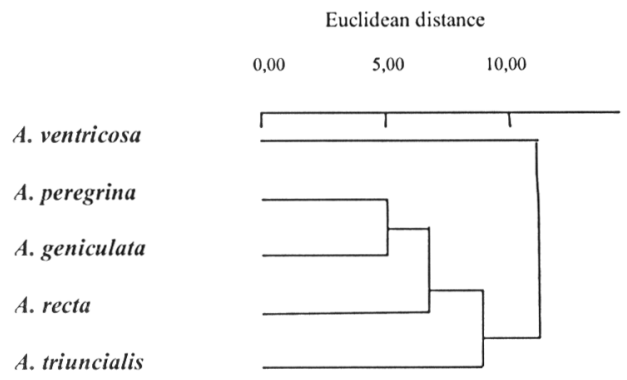

Fig 4. Dendrogram of 139 Moroccan Aegilops accessions obtained by analysis of 28 specific morphological traits. Dendrogramme de 139 accessions Aegilops Marocaines obtenues par analyse de 28 caractères morphologiques spécifiques.

genetic structure of the whole collection of Moroccan Aegilops where molecular markers are being used. Studying the genetic variability within the Moroccan Aegilops collection should be potentially of great value for the wheat improvement programs within the country and worldwide.

ACKNOWLEDGEMENTS. This work was supported by a Research Project of the FrancoMaroccan cooperation PRAD (Projet de Recherche Agronomique pour le Développement) $n^{\circ}$ 99-2. We thank F. Gabon for help with data statistical analysis.

\section{REFERENCES}

ALLARD, R. W. - 1988- Genetic changes associated with the evolution of adapted ness in cultivated plants and their wild progenitors. Journal of Heredity 79 : 225-238.

BADAENA E.D., B. FRIEBE \& B.S. GILL -1996Genome differentiation in Aegilops 2. Physical mapping of $5 \mathrm{~S}$ and $18 \mathrm{~S}-26 \mathrm{~S}$ ribosomal RNA gene families in diploid species. Genome 39: 1150-1158.

BAUM, B. -1977- Taxonomy of the tribe Triticeae (Poaceae) using various numerical techniques.I. Historical perspectives, data accumulation, and character analysis. Can. J. Bot. 55 : 1712-1740.
BAUM B. -1978a- Taxonomy of the tribe Triticeae (Poaceae) using various numerical techniques.II. Classification. Can. J. Bot. 56: 27-56.

BAUM B. $-1978 b$ - Taxonomy of the tribe Triticeae (Poaceae) using various numerical techniques.III. Synoptic Key to genera and synopses. Can. J. Bot. 56: 374-385.

BAUM B.R., J.R. ESTES \& P.K. GUPTA-1987Assessment of the genomic system of classification in the Triticeae. Am. J. Bot. 74: 1388-1395.

BENLHABIB O., G. DIRIA, M. BOUHSSINI S. LHALOUI \& M. NACHIT -2001- Characterization of Moroccan Aegilops ssp. for germoplasm enhancement, Actes I.A.V: 21 (4): 193-198.

BOISSIER P. E. -1884- Flora Orientalis 5:2, Basel, Geneva, Switzerland.

BOR N.L. GRAMINEAE, IN. TOWNSEND C. C., GUEST E., AL-RAWI E. AND A. (eds.) -1968Flora of Iraq, vol. 9, Baghdad, Iraq: Ministry of Agriculture.

CHENNAVEERAIAH, M.S. -1960- Karyomorphologic and cytotaxonomic studies in Aegilops. Acta hortigotoburgensis 23: 85-178.

DAMANIA A. B. -1993-Biodiversity and wheat Improvement, Jhon Wiley \& Sons, ICARDA.

DAVIS P.H. \& V.H. HEYWOOD -1973-Principals of Angiosperm plant taxonomy. Robert E. Krieger publishing company, Huntington, New York.

EIG A. -1929a-Monographische-Kritische Uebersicht der Gattung Aegilops, Fedde Repport. Reg. Veget. Beib., Band Lv. Berlin 55: 1-228.

GUPTA P.K. \& B.R. BAUM-1986- Nomenclature and related taxonomic issues in wheat, triticales and some of their wild relatives. Taxon 35: 145.

HACKEL E. -1887-Gramineae, in Die Natürlichen pflanzenfamilien, vol2 (2), A. Engler and Prantel: 76-89.

HAMMER K. -1980- Zur Taxonomic and Nomenklatur der Gattung Aegilops L. Feeddes Report. 91: 225-58.

KIHARA H. -1946- Genomeanalyse bei Triticum und Aegilops IX. Systematischer Aufbau der Gattung Aegilops auf genomanalytischer Grundlage. Cytologia 14: 135-144.

KIMBER G. \& M. FELDMAN -1987- Wild wheat, An introduction, special Report 353, University of Missouri, USA.

KIMBER G. (eds.) -1983- The B genome of wheat: the present status, Cytogenetics of Crop Plants, 
Macmillan India, New delhi, In: Swaminathan, M.S., Gupta P.K. and Sinha U.: 213-224.

LLAURADÓ M. \& J. MORENO-GONZALEZ 1993- Classification of northen Spanish populations of maize by numerical taxonomy I. Morphological traits. Maydica 38: 151-152.

JUSSIEU, A.L. -1789- Genera plantarum, 28.

LÖVE, A. -1984- Conspectus of the Triticeae. Feddes Repert. 95 : 503-504.

MAIRE, R. -1955-Flore de l'Afrique du nord. Le chevalier P, III Paris VI: 349-365.

MONTE J.V., C. CASANOVA \& C. SOLER -1999-

Genetic variation in Spanish populations of the genus Aegilops revealed by RAPD. Agronomie 19: 419-427.

PERINO P. \& E. PORCEDDU-1990- Wheat genetic resources in Ethiopia and the Mediterranean region, In Srivastava, J.P. and Damania, A.B. (eds) Wheat Genetic Resources: Meeting Diverse Needs. Chichester, UK: John Wiley.

PILGER, R. -1945- Additamenta agrostologica I. Triticeae, Bot. Jahrb. Syst. Pflanzengesch. Pflanzengeogr. 74: 1-13.

QUERZEL T.\& S. SANTA -1962/1963- Nouvelle flore de l'Algérie et Des Régions Désertiques Méridionales. 2 tomes, centre national de la recherche scientifique, Paris, 157.

SAKAMOTO S. \& H. KOBAYASHI -1980Variation and geographical distribution of cultivated plants, their wild relatives and weeds native to Turkey, Greece and Romania. Reprint from: Tani Y., Preliminary report of comparative studies on the agrico-pastoral peoples in southwestern Eurasia, II. Research Institute for the Humanistic Studies, Kyoto University, Japan: 41-104.

SAKAMURA, T. -1918- Kurze Mitteilung uber die chromosomenzahlen und die verwandt Schaftsverhaltnisse der Triticum-Arten. Bot. Mag., Tokyo 32: 151-152.

SAS INSTITUT -1989- SAS/STAT user's guide, version 6, 4th edn SAS institut Inc., Cary, North Carolina.

SEARS, E.R. -1941- Amphidiploids in the sevenchromosome Triticeae, Univ. Missouri Coll. Agric. Agric. Exper. Sta., Res. Bull. 336: 1-46.

SENJANINOVA-KORCZAGINA, M.V. -1932Karyo-systematical investigation of the genus Aegilops L. Bull. Appl. Bot., Gen. Pl. Breeding, Ser.2, vol. 11, 1: 60-66.
SHARMA, H.C. - 1982- A technique for somatic counts from root tips of cereal seedlings raised by embryo culture. Current Science 55: 143-144.

STEBBINS, G.L. \& B. CRAMPTON -1959- A suggested revision of the grass genera of temperate North America. Recent Adv. Bot. 1: 133-145.

VALDÉS, B., M. REJDALI, A. ACHHAL EL KADMIRI, S.L JURY \& J.M. MONTSERRAT -2002- Catalogue des plantes vasculaires du nord du Maroc, incluant des clés d'identification. Consejo Superior de Investigaciones Cientificas 2: 807-809.

VAN SLAGEREN, M.W. -1994- Wild wheats: A monograph of Aegilops L. and Amblyopyrun. (Jaub. \& Spach) Eig (Poaceae), Agricultural University ICARDA, Wageningen, the Netherlands.

WAINS, J.G. \& D. BARNHART -1991Biosystematic research in Aegilops and Triticum. Hereditas 116: 207-212.

ZAHARIEVA, M. N., J. DAVID, D. THIS \& P. MONNEVEUX -1999- Analyse de la diversité génétique d'Aegilops geniculata Roth en Bulgarie. Cahiers Agricultures 8: 181-188.

ZHUKOVSKY,P.M.-1928-A critical-systematical survey of the species of the genus Aegilops L. Bull. Appl. Botany, Genet. Plant Breeding 18:417-609.

ZOHARY, D. \& M. FELDMAN -1962Hybridization between amphidiploids and the evolution of polyploids in the wheat (AegilopsTriticum) group, Evolution 16: 44-61.

ZURABISHVILI, T.G., A.B. IORDANSKY \& N.S. BADAEV -1978- Linear differentiation of cereal chromosomes. II. Polyploid wheats. Theor. Appl. Genet. 51: 201-210.

Aceptado para su publicación en septiembre de 2003

Adress of the authors. B. BELKADI: Laboratoire de Microbiologie et de Biologie Moléculaire, Université Mohamed V, Faculté des Sciences B.P.1014, Rabat, Maroc; N. ASSALI and O. BENLHABIB: Unité de Biotechnologie Cellulaire et Moléculaire, Département d'Agronomie et d'amélioration des plantes, I.A.V. Hassan II, RabatInstituts, Maroc. 